\title{
Allergic Effect of Kinesio Tape on a Child with Spastic Cerebral Palsy: Case Report
}

\author{
Alaa Noureldeen Kora*1, Faten H Abdelazeim ${ }^{1}$, Khaled A Olama ${ }^{1}$ and Ehab R Abdol Raouf ${ }^{2}$ \\ ${ }^{1}$ Department of Physical Therapy for Paediatrics, Cairo University, Egypt \\ ${ }^{2}$ Department of Research on Children with Special Needs, National Research Center, Egypt
}

Submission: September 21, 2018; Published: October 22, 2018

*Corresponding author: Alaa Noureldeen Kora, Department of Physical Therapy for Paediatrics, Faculty of Physical Therapy, Cairo University, 7 Ahmed EL Zayat St. Bien El sarayat, Dokki, Giza, Egypt 11432, Egypt, Tel: 00201002701815; Email: alaan.kora@gmail.com

\begin{abstract}
Background and purpose: Kinesio taping is widely used now on pediatric population. Recently, it has been used to promote function facilitate muscle action and inhibit spasticity of children with cerebral palsy. The aim of this article to highlight an existing problem we faced during the applying of kinesio tape on a child with spastic cerebral palsy which is skin allergy.

Methods: Muscle Inhibitory Kinesio tape was applied on the calf muscle of a female child of spastic cerebral palsy, in order to inhibit muscle spasticity.

Results: Despite the child had passed the sensitivity test, after 2 kinesio tape applications, a skin allergic reaction appeared.

Conclusion: A skin allergy may appear after using the kinesio tape despite passing a pre-application sensitivity test.

Keywords: Kinesio tape; Skin; Allergy; Spasticity; Cerebral palsy

Abbreviations: KT: Kinesio taping; GMFCS: Gross Motor Function Classification System; PDMS: Peabody Developmental Motor Scales; H/M: Hoffman Reflex/Muscle Response Ratio
\end{abstract}

\section{Introduction}

Kinesio taping (KT) application is a relatively new technique used in the rehabilitation of children with spastic cerebral palsy [1]. KT is a thin, elastic tape with thickness and elastic properties similar to skin. KT is applied directly onto the skin [2]. It is made of $100 \%$ cotton with elastic properties which allows KT to work with soft body tissues. KT is free of latex and is applied to the backing paper with $10 \%$ available stretch, and it can be stretched $40-60 \%$ from the resting length. The adhesive on the KT is medical grade acrylic which is heat sensitive. To apply the KT on the skin, it must be rubbed in order to adhere [3].

KT is applied to the skin and as in every method which contact the patient, it must be sure that it doesn't produce any harm. A sensitivity test via a test patch is applied prior KT application [4].

\section{Patient Information}

We are reporting a 2year, 7 months female with spastic cerebral palsy; Spasticity appeared unilaterally on the left side of her body (left hemiparesis). She is on level II on gross motor function classification system (GMFCS). Her developmental age was 9 months according to Peabody developmental motor scales (PDMS). No medications were taken except Omega 3.

\section{Methods}

\section{Evaluation materials}

Modified Ashwar scale was used to evaluate the degree of spasticity which was graded 1 , which meant a mild spasticity.

Hoffman Reflex/Muscle response ratio (H/M) ratio was performed to clarify the presence of spasticity, and it was confirmed that there was a presence of spasticity on the left soleus muscle GMFCS was used to declare her level of gross motor function; she was on level II which means that the child can be locomotive using assistive aid or cursing on objects and furniture.

\section{Management materials}

KT was chosen to be applied in a muscle inhibitory manner, in order to inhibit the soleus muscle spasticity as supported by Karadag-Saygi et al. [5].

A sensitivity test was applied to the patient to discover if she had any allergy to the KT or not. The skin was cleaned carefully to remove any oil or dirt via water. A test patch was cut $5 \mathrm{~cm} \mathrm{x}$ $5 \mathrm{~cm}$ square, it was placed on the soleus muscle and it was left 
for 3 successive days. The child was monitored by her care giver and she reported that no itchy sensation by the child nor a red patch appeared.

After the child passed the test, The KT was applied for the purpose of calf muscle inhibition. Prior the application the skin was cleaned probably via water.

One Y strap was prepared for the child. Maximum stretch of calf muscle was applied, then the distance from tendonachllis and the crease of the knee was measured. The KT was cut according to the measured distance. The Y strap was applied from insertion (anchor) to origin direction (base) from the tendonachllis to the origin of soles muscle and gastrocnemius with $15 \%$ stretch of the tape length, and then rubbed to adhere probably to the skin. The KT was applied for six days and removed for 1 day as supported by Gómez-Soriano et al. [6] to allow skin perspiration.

\section{Observation and Outcome}

It was planned that the child would receive 12 sessions of KT application besides her regular physical therapy sessions, but only after her second KT application it was reported that child was in a continuous crying and her skin was very irritating surrounding the tape, Also the skin covering the left calf muscle was started to swell. The KT was removed immediately after this notice and the area was cleaned properly via cold water to remove any excess adhesive parts from the tape and to decrease the irritation.

The mentioned allergy manifestations stopped after removing the tape just in few hours. We stopped the usage of KT application for this child.

\section{Discussion}

This study noticed a skin allergic reaction of KT on a child with spastic cerebral palsy. KT is a great technique that is less invasive to children due to its thin and elastic structure that is similar to human skin tissue [2]. It is latex Free and formed $100 \%$ of cotton [7] which made it more likely to be less allergic to children skin. It wasn't the first time that it was reported a case of skin allergy after KT application. It was reported before that a neurologic patient with tetraplegia showed a skin allergy following the use of KT [8]. A multi-centre study was performed in four countries revealed that the incidence of skin reaction to patients who used KT may reach 9.38\% [9].

In previous studies we already report the presence of skin allergic reaction after taping application, although all precautions, preparations, sensitivity test and even proper KT application was ensured [10-11]. Another observational study of sixty neurological cases revealed that KT can cause Kinesio tape can cause allergies [12].
Some suggested factors that may cause allergy, although a further research is needed, such as applying to much stretch to the KT, applying stretch to the anchor, hair follicle irritation to the unshaved areas and skin irritation of fleshy shaft areas [13]. Regular checking up of skin following KT application is a must, to notice any allergic reaction.

\section{Conclusion}

The KT sensitivity test is essential prior any KT application but still it is not a total grantee. Some patients may pass the test successfully but may be- later on - show allergic reaction to the KT, even with proper application.

\section{References}

1. Shamsoddini A, Rasti Z, Kalantari M, Hollisaz M, Sobhani V, et al. (2016) The impact of Kinesio taping technique on children with cerebral palsy. Iran J Neurol 15(2): 219-227.

2. Morris D, Jones D, Ryan H, Ryan C (2012) The clinical effects of Kinesio ${ }^{\circ}$ Tex taping: A systematic review. Physiother Theory Pract 29(4):259-270.

3. Yasukawa A, Martin P, Kase $K(2006)$ Kinesio taping $®$ in pediatrics. ( $1^{\text {st }}$ edn). In: Albuquerque NM (Edn) (Kinesio Taping Association.

4. De Ru E, Heukels H, Kaspers H (2013) Elastic therapeutic taping in peadiatrics. $\left(1^{\text {st }}\right.$ edn). Go Physio Zutphen NL.

5. Karadag-Saygi E, Cubukcu-Aydoseli K, Kablan N, Ofluoglu D (2010) The Role of Kinesiotaping Combined with Botulinum Toxin to Reduce Plantar Flexors Spasticity After Stroke. Top Stroke Rehabil 17(4): 318322.

6. Gómez-Soriano J, Abián-Vicén J, Aparicio-García C, Ruiz-Lázaro P, Simón-Martínez C, et al. (2014) The effects of Kinesio taping on muscle tone in healthy subjects: A double-blind, placebo-controlled crossover trial. Man Ther 19(2):131-136.

7. Unger M, Carstens J, Fernandes N, Pretorius R, Pronk S, Robinson A et al. (2018) The efficacy of kinesiology taping for improving gross motor function in children with cerebral palsy: A systematic review. S Afr J Physiother 74(1): 459.

8. Mikołajewska E (2010) Allergy in patients treated with kinesiology taping: A case report. Medical Rehabilitation 14(4): 29-32.

9. De Ru E, Mikołajewska E (2017) Skin irritation incidence following kinesiology tape use in patients with neurological disorders: multicenter observation. Annales Academiae Medicae Silesiensis 71: 7-13.

10. Kora A, Abdelazeim F, Olama K, Abdol Raouf E, Abdelraouf O (2018) Muscle Inhibitory Vs Functional Corrective Kinesio Taping on Gross Motor Functional Abilities in Children with Spastic Cerebral Palsy. Journal of Complementary and Alternative Medical Research 6(1): 1-9.

11. Kora A, Abdelazeim F, Olama K, Abdol Raouf E, Abdelraouf O (2018) Effect of Different Kinesio Taping Applications on Ankle Range in Children with Spastic Cerebral Palsy: A Comparative Study. Asian Journal of Advanced Research and Reports 1(3): 1-8.

12. Mikołajewska E (2011) Side Effects of Kinesiotaping - Own Observations. Journal of Health Sciences 1(4): 93-99.

13. http://www.athletictapeinfo.com/tag/kinesio-tape-skin-irritation/ 
This work is licensed under Creative Commons Attribution 4.0 License

DOI: 10.19080/JCMAH.2018.08.555735
Your next submission with Juniper Publishers will reach you the below assets

- Quality Editorial service

- Swift Peer Review

- Reprints availability

- E-prints Service

- Manuscript Podcast for convenient understanding

- Global attainment for your research

- Manuscript accessibility in different formats

( Pdf, E-pub, Full Text, Audio)

- Unceasing customer service

Track the below URL for one-step submission https://juniperpublishers.com/online-submission.php 